\title{
The Antecedents were affecting Employee Job Performance Lesson Learned from Universitas Bengkulu
}

\author{
Gerry Suryosukmono ${ }^{1}$, Praningrum ${ }^{2}$, Anggri Puspita Sari ${ }^{3}$ \\ Faculty of Economic and Business - Bengkulu University ${ }^{1,2,3}$ \\ \{gerrysuryo@unib.ac.id ${ }^{1}$,praningrum@unib.ac.id², apuspitasari@unib.ac.id ${ }^{3}$ \}
}

\begin{abstract}
This research aims to analyze the effect of transformational leadership, organizational culture, and innovative behavior to increase the degree of employee job performance. The research of the population was permanent employees from the Faculty of Economics and Business and Faculty of Teaching and Education Science which amount to 80 people determined by the convenience sampling method. The research method starting by running a pretest using Cronbach Alpha and factor analysis continue by validity and reliability test using Confirmator y Factor Analysis. Next, we are using multiple regression analysis to test theoretical analysis. The results of these studies show a significant effect between transformation leadership and organizational culture on employee performance. Besides that, the effect also emerged from the influence of innovation behavior to employee job performance even though not as significant as the two previous variables.
\end{abstract}

Keywords: Transformational Leadership; Organizational Culture; Innovation Behavior; Employee Job Performance

\section{Introduction}

Organizations are social entities that are coordinated consciously, with relatively identifiable boundaries, working continuously to achieve goals [1]. The occurrence of interaction between employees and employees with the leadership means that personal characteristics are blended with the values that already exist in the organization, which is formed as guidelines, ethics and work styles in the organization. So consequently, every member or employee in the organization cannot possibly be separated from the culture that exists in the organization. Even so, the behavior is still needed to innovate, explore new ideas and problem-solving solutions even though in practice, it is still synergized with the existing organizational culture. Here it will be seen the importance of the role of the leader, namely the manager as a good facilitator and also as a mentor who can help the members of the organization or employees to be able to adjust to their work culture while still being able to innovate. Managers are the spearheads who are expected to translate organizational goals into concrete actions and control employee actions to match the goals expected by the organization. 
In terms of the leadership model, transformational leadership is considered an alternative, especially for civil servants, to boost bureaucratic rigidity. Mc Nesse-Smith (1996), in his research, examines five transformational leadership behaviors (process challenges, inspiration, shared vision, enabling others to act, modeling ways, encouraging enthusiasm). This study then identified the relationship (both correlational and predictive) between the use of leadership behavior and employee performance, employee job satisfaction, and organizational commitment. This study supports a positive relationship between the use of leadership behavior and employee performance.

In terms of culture itself, Schein [2] observes that organizational culture and leadership are interrelated. He illustrates this interconnection by looking at the relationship between leadership and culture in the context of the organizational life cycle. In general, organizational culture is on the other hand, the decline in employee performance occurs due to the lack of innovation and creativity that can be channeled, especially for civil servants. On that basis, the behavior to always innovate is a behavior that is also important to be cultivated. Wu, Parker \& De Jong [3] define innovation behavior as behavior in the process of creating, introducing, and applying new ideas in either a work function, group, or organization to improve the performance of the role, group or organization. Innovation behavior starts from the process of recognizing the problem faced along with the process of finding ideas or solutions and ends with building supporting factors for implementing the idea [4]. Organizations that sometimes have to be able to adjust to the situation flexibly cannot act because of the bureaucracy that sometimes hinders them. It is where the integration between transformational leadership styles, constructive organizational culture, and fostering innovative behavior must be able to synergize well, which in turn is expected to improve employee performance.

Things like this in the future will significantly impact organizational performance. Where in the current era of globalization demands high organizational performance to be able to survive during a very extreme level of competition, especially in 2025, the University of Bengkulu declared the vision of "Becoming a Superior University in the Implementation of World Class Higher Education" so that all elements of organizational functions including increased performance Bengkulu University human resources are critical. It is where the strategic function of the institution plays a role in coordinating and integrating good leadership, organizational culture, and innovation behavior to create performance improvements as expected.From the explanation described in the background, by identifying and examining various factors, it is hoped that a description of the matters related to improving employee performance is obtained. This research tries to study these factors, namely the influence of transformational leadership style, organizational culture, and innovation behavior in improving the performance of Bengkulu University employees.

\section{Literature Review}

\subsection{Transformational Leadership}

Luthans [5] argues that transformational leaders use legitimacy tactics more often and produce higher levels of identification and internalization, have better performance, and develop followers. According to Robbins and Judge [6], transformational leadership is superior to transactional leadership. It produces levels of follower effort and performance that go beyond what could be achieved if the leader only adopted a transactional approach. 
According to Robbins and Judge [6], there are four dimensions of transformational leadership, namely:

a. Idealized Influence. Idealized influence is a leader's behavior that provides a vision and mission, creates a sense of pride, and earns respect and trust from subordinates. Idealized influence is also known as a charismatic leader, where followers have deep confidence in the leader, feel proud to be able to work with the leader, and trust in the leader's capacity to solve every problem.

b. Inspirational Motivation. Inspirational motivation is the behavior of a leader who can communicate high expectations, attractively convey a shared vision by using symbols to focus the efforts of subordinates and inspire subordinates to achieve goals that produce actual progress for the organization.

c. Intellectual Stimulation. Intellectual stimulation is a leader behavior that can increase the intelligence of subordinates to increase their creativity and innovation, increase rationality, and solve problems carefully.

d. Individualized Consideration. Individualized consideration is the behavior of a leader who pays personal attention, treats each subordinate individually as an individual with different needs, abilities, and aspirations, and trains and provides suggestions. Individualized consideration of transformational leadership treats each subordinate as an individual as well as accompanies them, monitors, and fosters opportunities.

Cavazotte \& Hickman [7] view transformational leadership as four differences and components that are related but conceptually in charisma (ideal influence), the leader shows confidence; emphasize trust; endure difficult circumstances; display important self-values; emphasizes the importance of intention, commitment, and the ethical consequences of decisions. In inspirational motivation, the eader emphasizes an attractive view of the future, challenges followers with high standards, speaks optimistically with enthusiasm and provides enthusiasm and meaning for what to do.

In intellectual stimulation, the leader asks old assumptions, traditions, and beliefs, stimulates new perspectives and ways of doing things, and encourages the expression of ideas and reasons that will strengthen the thought processes of subordinates. In individual considerations, leaders deal with others as individuals; take into account their individual needs, abilities, and aspirations; listen attentively; further their development; to advise; teaching; and train [8]. In transactional leadership, the leader-follower relationship is based on a series of exchanges or bargains between the leader and followers. Bass [9] distinguishes two factors that form the basis of the level of activity of leaders and the nature of interactions with subordinates.

\subsection{Organizational Culture}

Organizational culture is a system of meanings, values, and beliefs that are shared in an organization, which becomes a reference for action and differentiates organizations from one another [10]. The organizational culture then becomes the identity or the main character of the organization that is maintained and maintained [10]. Robins [1] states that organizational culture is a system of shared meanings adopted by organizational members that differentiate the organization from other organizations. Organizational culture is a value system that is acquired and developed by the organization and the habit patterns and basic philosophy of its founders, which are formed into rules that are used as guidelines for thinking and acting in achieving organizational goals. A culture that grows strong can spur the organization towards better development. 
In general, organizational culture is defined as a series of values, beliefs, and behavior patterns that shape the organizational identity and behavior of its members [11]. Stoner et al. [12] stated that culture (culture) is a complex combination of assumptions, behavior, stories, myths, metaphors, and various other ideas that come together to determine what it means to be a member of a particular society. Meanwhile, organizational culture is several essential understandings, such as norms, attitudes, and beliefs, which are shared by members of the organization. According to Schein [2], culture exists in three levels, namely:

a. Artifact (Artifacts): things that exist together to define culture and reveal what culture is to those who define the culture. Artifact includes products, services, and even the behavior patterns of members of an organization.

b. Supported values (espoused values): The reasons an organization gives for supporting the way it does something.

c. Basic Assumption: Beliefs that are considered to already exist by members of an organization.

Wilderom \& Van Den Berg [13], in their opinion explaining the dimensions of organizational culture include orientation improvement (Improvement orientation ), empowerment ( Empowerment), the orientation of the external (External Orientation), cooperation between departments (interdepartmental Cooperation), and the orientation-based human resources ( HR Orientation ).

\subsection{Innovative Behavior}

The word innovation itself refers to the opinion of Damanpour [14] is the process of producing, developing or adopting a set of ideas or behavior. In other terms, innovation can refer to the creation of new products or services, new processes, new administrative structures or systems, or new plans produced by organizational members [15]. So it can be concluded that the concept of innovation can be embedded in the process of creating something new or the output of a process such as behavior.

Janssen [16] defines innovation behavior at work as behavior in the process of creating, introducing, and applying new ideas in either a work function, group or organization to improve the performance of the role, group or organization. In line with this statement, the innovative behavior of the opinion of Wu, Parker \& De Jong [3] is the behavior or attitude of hard work of individuals who create, introduce or implement new ideas. Innovation behavior starts from the process of recognizing the problem faced along with the process of finding ideas or solutions and ends with building supporting factors for implementing the idea [4]. Examples of innovation behavior include looking for new technological alternatives, formulating new ways to achieve goals, applying new work methods or looking for alternative resources to formulate new ideas [17], [16]. From these various opinions, it can be concluded that innovation behavior is a complex behavior consisting of a series of activities to produce new ideas (either by themselves or replication) or the realization and implementation of new ideas [4]

Innovation work behavior is divided into four dimensions, namely idea exploration, idea generation, idea championing, and idea implementation [18]. The innovation process begins with the process of discovering ideas as a solution to a problem and services that are already running or to try to think of alternative solutions to improve their quality [17]. Furthermore, the process of generating ideas (idea generation ) which contain a combination and reorganization of existing information and concepts to solve problems or improve performance [18]. A good idea generator can analyze the gaps between problems and performance from multiple points of view [17] that arises. Exploration of ideas 
is also carried out to find ways to improve the quality of goods.

The next stage is the stage of fighting for ideas (idea championing). The ideas that have been generated must be struggled for legitimacy and not get obstacles to their application. Fighting for ideas includes the process of seeking support and building coalitions based on the belief in the success of the idea and involving the right people to implement the idea [19]. Lastly is the implementation of ideas. It takes a result-oriented effort and attitude to make the idea work. Implementation of ideas includes changing behavior to develop a product or work process and how to modify work attitudes for the better [18].

\subsection{Employee Job Performance}

Performance is a set of results that are achieved and refers to the achievement of actions and the implementation of the requested work [20] According to Campbell, McCloy, Oppler \& Sager [21] performance is defined as the things that the organization wants in recruiting employees. That employee can do it well provided that it can be measured to state whether the behavior includes the performance or not. The performance itself must be measured based on an evaluation of the processes that occur to produce an item [22] [23]. In another sense, performance means the actual level of work performed by employees [24].

According to Irving in Surya and Hananto [25], an essential component for assessing performance is the quantity and quality of individual performance. It is assessed based on the achievement of the quantity and quality of output resulting from a series of tasks that must be performed. John \& Russel (1993) stated that performance is a record of success resulting from the function of a particular job/activity during a specific period. According to him, there are six categories to measure employee performance, namely quality, quantity, timeliness, effectiveness, independence and work commitment.

\section{Research Methods}

\subsection{Research Design}

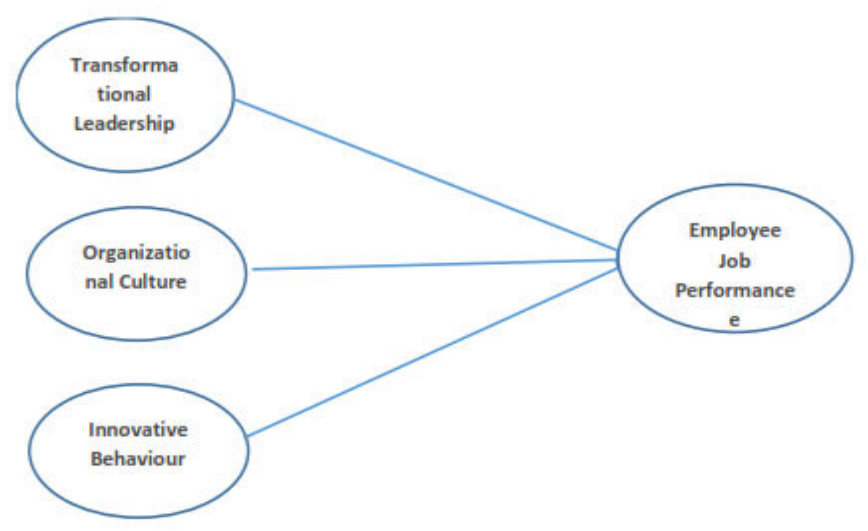

Fig. 1. Research Hypotheses 
H1: Transformational leadership has a positive effect on employee job performance

$\mathrm{H} 2$ : Organizational culture has a positive effect on employee job performance

H3: Innovative Behaviour has a positive effect on employee job performance

\subsection{Sampling and Analysis Method}

The scope of this research is the influence of transformational leadership, organizational culture, and innovation behavior on improving employee performance by taking a case study at Bengkulu University. The selection of the research location (sampling) was carried out in the employee environment consisting of operational staff or teaching staff (lecturers) and structural / non-technical staff (staff, sub- division and head of division) in Bengkulu University. The locations and objects to be examined are the five most prominent faculties in the University of Bengkulu, namely the Faculty of KIP, Faculty of Economics and Business (FEB), Faculty of Agriculture, Faculty of Mathematics and Natural Sciences, and Faculty of Engineering. The consideration of choosing Bengkulu University is based on Unib's vision in 2025 "To become a leading university in the implementation of world-class higher education, researchers want to see the readiness of Bengkulu University towards this vision, one of which is by looking at aspects of its human resource performance.

The population of this study included all Bengkulu University employees consisting of functional or teaching staff (lecturers) and structural / non-technical staff (staff, sub- division heads, and heads of department). The reason why the author chose this population is that the author wants to know what aspects of transformational leadership and organizational culture, and innovation behavior and how far they influence the improvement of employee performance at Bengkulu University.

According to Roscoe's opinion in Sugiyono [26], he suggests that in the study, the limit of the number of samples used is between 30 samples to 500 samples. The number of samples taken was 80 people from the five most prominent faculties with the assumption of 16 people from each faculty. In this case, the sampling technique used was purposive sampling because the sample selection met the criteria set by the researcher and probability sampling. After all, every respondent who had population criteria had the same opportunity to become a sample.

Table 1. Respondent Profile

\begin{tabular}{ccc}
\multicolumn{3}{c}{ Table 1. Respondent Profile } \\
\hline Gender & Frequency & Percentage \\
Male & 37 & $46,25 \%$ \\
Female & 43 & $53,75 \%$ \\
Total & 80 & $100 \%$ \\
Status & Frequency & Percentage \\
Married & 45 & $56,25 \%$ \\
Single & 30 & $37,5 \%$ \\
Divorced & 5 & $6,25 \%$ \\
Total & 80 & 100 \\
Age & Frequency & Percentage \\
21-30 years & 10 & $33,33 \%$ \\
31-40 years & 31 & $38,33 \%$ \\
41-50 years & 33 & $13,33 \%$ \\
51-60 years & 6 & $10 \%$ \\
Total & 60 & 100 \\
Educational Rate & Frequency & Percentage \\
High School & 3 & $3,75 \%$ \\
Diploma & 2 & $2,5 \%$ \\
\hline
\end{tabular}




\begin{tabular}{ccc}
\hline Bachelor & 10 & $12,5 \%$ \\
Master & 38 & $47,5 \%$ \\
Doctor & 27 & $33,75 \%$ \\
Total & 80 & 100 \\
Years of Service & Frequency & Percentage \\
Less than one year & 2 & $2,5 \%$ \\
$1-10$ years & 9 & $11,25 \%$ \\
$11-20$ years & 34 & $42,5 \%$ \\
21-30 years & 31 & $38,75 \%$ \\
More than 30 years & 4 & $5 \%$ \\
\hline
\end{tabular}

Based on the table, it can be seen that women with $53.75 \%$ dominate the percentage of respondents. With a total of 43 people from 80 respondents, it cannot be separated from the number of female employees who are more than male employees at the University of Bengkulu as a whole. Besides, it can be seen that women with $53.75 \%$ dominate the percentage of respondents. As for the number of respondents who are married has the largest number with $56.25 \%$ or 45 people from 80 respondents. It happens because the structure of the teaching staff (lecturers) with an average education level of S2 is generally married either before or after joining Bengkulu University.

Besides, the average age of the respondents is in the range of 40-50 years and the age range of $30-40$ years, which is the age of someone who is generally married. In the age group, it is seen that the two age groups that have the most influence on the age structure of the respondents are the mean age of the respondents in the range of 31-40 years and 41-50 years. It will affect other factors such as tenure in the organization, status, and position within the organization. In terms of education level, it can be seen that the average education level of respondents is at the master (S2) and doctoral (S3) levels. That is understandable, considering that on average, the respondents of the employees studied were lecturers.

The other education levels (S1, Diploma and SMA) come from non-teaching staff and personnel. In the table, it can also be seen that most respondents have worked in organizations with a period of between 11-20 years and 21-30 years, respectively, with a total of 34 and 31 respondents. It is not surprising, considering that the employees who mostly come from teaching staff (lecturers) retire at the age of 65 for ordinary lecturers and 70 years for professors. The position of the teaching staff also has the largest percentage with $52.5 \%$ or 42 respondents out of 80 people. When viewed from one of the variables, namely innovation behavior, work focus that allows for innovation can be done more by operational staff such as educators than structural staff.

\subsection{Measurement}

Researchers used regression analysis to analyze the independent variables against the dependent variable. This calculation method analysis is carried out with the SPSS program. Regression analysis involves one dependent variable and two or more independent variables. Questions raised in the context of bivariate regression can also be answered through multiple regression by considering additional independent variables [27]. The general form of the regression model is as follows:

$\mathrm{Y}=\beta \mathrm{o}+\beta 1 \mathrm{X} 1+\beta 2+\mathrm{X} 2+\beta 3+\mathrm{X} 3+\cdots+\beta \mathrm{KXk}+\mathrm{e}$

which is estimated by the following equation: 
$\mathrm{Y}=\mathrm{a}+\mathrm{b} 1 \mathrm{x} 1+\mathrm{b} 2 \mathrm{X} 2+\mathrm{b} 3 \mathrm{X} 3+\ldots .+\mathrm{bkXk}$

While this research model is:

$\mathrm{Y}=\mathrm{a}+\mathrm{b} 1 \mathrm{x} 1+\mathrm{b} 2 \mathrm{X} 2+\mathrm{b} 2 \mathrm{X} 3$ e means:

$\mathrm{Y}=$ Employee Performance $\mathrm{a}=$ Number Constant

b1x1 = Transformational Leadership b2X2 = Organizational Culture

b3X3 = Innovation Behavior $\mathrm{e}=$ standard error

Also, researchers used the t-test (partial test) using the partial coefficient test of the independent variables on the dependent variable with the proposed hypothesis. The t-test shows how much influence a single dependent variable has. If the probability is smaller than 0.05 , the result means that there are independent variables that individually have a significant effect on the dependent variable [28]. If $t$ count $>t$ table or $p$-value in column sig <significant level (alpha) then Ho is rejected and $\mathrm{Ha}$ is accepted, partial means that there is influence between the independent variable and the dependent variable. Meanwhile, if $\mathrm{t}$ count $<\mathrm{t}$ table or $\mathrm{p}$-value in the sig column $<$ significant level (alpha) then Ha is rejected and Ho is accepted, meaning that there is no partial influence between the independent variable and the dependent variable.

Ho: Transformational leadership, organizational culture, and innovation behavior do not affect employee performance.

Ha: Transformational leadership, organizational culture and innovation behavior affect employee performance.

a. If $\mathrm{T}$ count $<\mathrm{t}$ table, then Ho is accepted. It means that using transformational leadership, organizational culture, and innovation behavior does not affect employee performance

b. If $\mathrm{T}$ count $>\mathrm{t}$ table, then Ho is rejected. It means that using transformational leadership, organizational culture, and innovation behavior affects employee performance.

\section{$4 \quad$ Result and Discussion}

\subsection{Research Result}

Table 2. Determination Coefficient

Model Summary

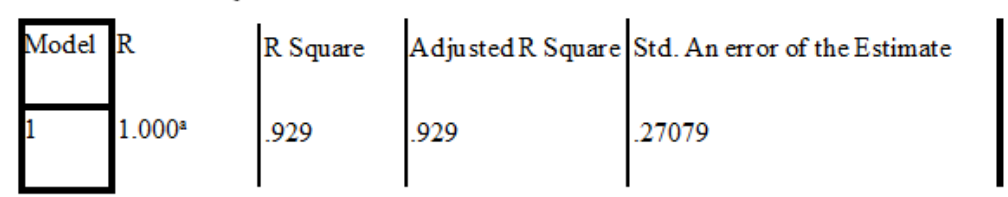

Predictors: (Constant) X1, X2, X3 b. Dependent Variable: Y

Primary data was reprocessed using SPSS 16

In terms of the coefficient of determination seen in table 5.12 above, the value of the Adjusted R Square is 0.929 or $92.9 \%$. The independent variables, namely transformational leadership, organizational culture and innovation behavior, have a significant impact on employee performance with an effect of $92.9 \%$. The residual coefficient which ranges from $7.1 \%$, is explained by other factors that were not taken into account in this study. 
Table 3. F Test

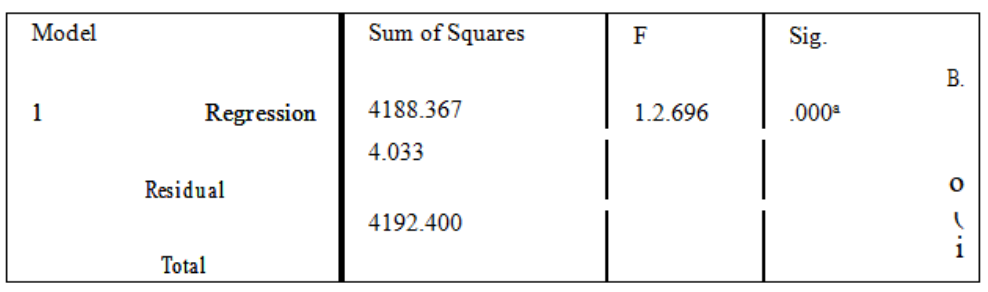

Besides, from the ANOVA test or F test conducted in table 5.13 above, the $\mathrm{F}$ test value is 12,696 with a probability / or sig value of 0.000 . Because the probability $(0.000)$ is smaller than 0.05 and the $F$ test value (12.696) is greater than the $F$ table value (2.725). The value of the $F$ table is obtained from the significant value of F 0.05 with df1 (number of variables-1) $=3$ and df2 (nk-1) or 80-3-1 = 76 ( $\mathrm{n}=$ number of data and $\mathrm{k}=$ number of independent variables) (Priyatno, 2012 ). From the $\mathrm{F}$ table, the value is 2,725 . The $\mathrm{F}$ test value is $12.696>2.725$ and the significance value is $0.000<0.05$, so it can be said that all independent variables (transformational leadership, organizational culture, and innovation behavior simultaneously(together) can affect employee performance.

Table 4. $t$ Test

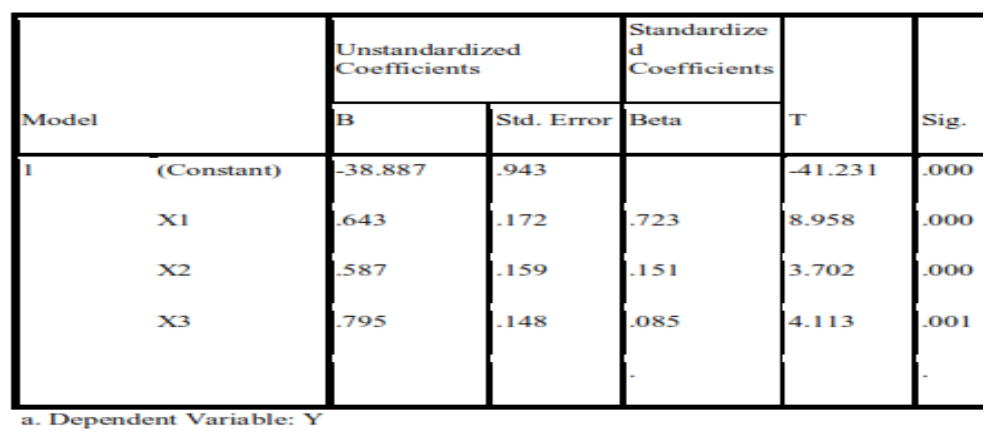

The table below shows the regression results of the coefficient of transformational leadership, job satisfaction, and organizational commitment, which are evidence that supports the significance of the relationship that occurs between variables. The regression coefficient with a value of $\mathrm{p}<0.05$ indicates that transformational leadership $(0.000)$, organizational culture $(0.000)$, and innovative behavior (0.001) significantly influence the increase in work performance value of $0.05 / 2=0.025$ with $\mathrm{df}(\mathrm{nk}-1)$ or $80-3-1=76(\mathrm{n}=$ number of data and $\mathrm{k}=$ number of independent variables) (Priyatno, 2012). So that the value is 1.992 from the t-table. In addition, there is a significant value of $0.000<0.05$. From these results, we can conclude that $\mathrm{Ho}$ is rejected and $\mathrm{H} 1$ is accepted, which means that there is a significant relationship between organizational culture and performance. It also means that there is a partial influence that is built between organizational culture and performance. These findings were conducted by Chen [29] which shows that organizational culture has a significant positive effect on organizational commitment, job satisfaction toward employee performance. Naranjo-Valencia, Jiménez- Jiménez \& Sanz-Valle [30] in their research study also revealed that organizational culture could be a driving force or an obstacle to performance depending on the values that the organizational culture carries. 


\subsection{Dicussion}

From the analysis of table 4 , we can see that the value of the calculation $t \quad(8.958)>$ t-table (1.992). The t-table value is btained from a significant value of $0.05 / 2=0.025$ with df $n k-1)$ or 80-3-1 = 76 ( $n=$ number of data and $\mathrm{k}=$ number of ndependent variables) [31]. So that the value of 1.992 is obtained from the t-table. Also, there is a significant value of 0.000 $<0.05$. From these results, we can conclude that Ho is rejected and H1 is accepted, which means that there is a significant relationship between transformational leadership and performance. It also means that there is a partial influence that is built between transformational leadership and performance. This is in line with research proposed by Piccolo \& Colquitt [32] and Trottier, Van Wart, \& Wan [35]. On average, employees at Bengkulu University view their direct superiors (in this case, the head of the department or head of subdivisions and heads of departments) as leaders who can be trusted and can guide their subordinates.

Besides, the familiarity factor that is built with the similarity of local languages is felt to be very beneficial because it makes it easier for leaders to convey a shared vision attractively by using symbols to focus the efforts of their subordinates. Besides, the behavior of leaders who pay personal attention, treat each subordinate individually as an individual with different needs, abilities, and aspirations is seen as traits of a leader that enable employees to improve their performance. In line with this, transformational leadership will also have a positive correlation

In its vision and mission, which is closely related to international exposure, it is indicated by the establishment of an international program at the Faculty of Economics and Business, making all members of this organization agree to restructure the culture within their organization considering that organizational culture is an agreement with the members of the organization or company so that it makes it easier to establish Broader agreement for the benefit of individuals. There is an orientation related to improvement, one of which is spurred by a decline in university rankings, empowerment (Empowerment) of lecturers in achieving both academic and non-academic achievements.

Lecturer empowerment is also carried out by encouraging lecturers to take part in international conferences and be involved as visiting lectures on overseas campuses. After that, in the aspect of external orientation (External Orientation), for example, with the existence of international accreditation starting with the Master of Management Study Program, which will soon be accredited by ABEST, increased collaboration with foreign universities in the context of joint research, student exchange, credit transfers and a series of other international programs. Which was designed by KSLI Bengkulu University and HR-based orientation (HR Orientation) through enhancing the capabilities of lecturers and staff such as language skills in preparing to become a global university? All aspects of organizational culture change from old culture to a new culture with an international focus as the foundation, making employees motivated to improve their performance. In this case, the teaching staff/lecturers, as functional employees, are motivated to increase the performance output in the form of the resulting studies.

For the third hypothesis, we can see that the value of the calculation $t \quad$ (4.113) $>t$-table (1.992). The t-table value is obtained from a significant value of $0.05 / 2=0.025$ with $\mathrm{df}$ (nk-1) or $80-3-1=76(\mathrm{n}=$ number of data and $\mathrm{k}=$ number of independent variables) [31]. So that the value of 1.992 is obtained from the t-table. In addition, there is a significant value of $0.000<0.05$. From these results, we can conclude that Ho is rejected and $\mathrm{H} 1$ is accepted, which means that there is a significant relationship between innovation behavior and performance. It also means that there is a partial influence built between innovation behavior and 
performance. It was conducted by Walumbwa, Cropanzano, \& Hartnell [33] which explains that the willingness of employees to adopt new ways of working is seen as an essential aspect in assessing employee performance in terms of work. Innovation behavior itself is closely related to performance because innovation behavior itself aims to explore new ideas to solve problems which will undoubtedly have a positive impact on work [34]. Employees at the University of Bengkulu, who mostly consist of educators (lecturers), have one of the task components in the form of teaching, research and community service. These three tasks are seen as tasks that require innovation in their completion. For example, teaching using e-learning, making teaching materials based on case study analysis and research by searching for the latest phenomena and issues that occur in society are two forms of activities that require new ideas in them. Innovation behavior, in this case, is the search for new ideas, improvement and search for solutions as well as problem-solving in alternative ways is positively proportional to the increase in performance which in this case is measured by BKD (Lecturer Workload Report). One of the indicators of performance output produced is also patent rights, books, works of copyright that are near related to innovation.

\section{Conclusion}

Partially, transformational leadership positively affects employee performance. Leaders are seen by employees at Bengkulu University as having confidence, giving enthusiasm, and meaning to what should be done. Leaders are also seen as being able to encourage the expression of ideas and reasons that will strengthen the thought processes of subordinates, consider the needs, abilities and aspirations of employees and play a role in advising; teaching; and train - the following opinion of Bass [8] in analyzing the type of transformational leadership. The results of the regression coefficient also, the existence of this type of transformational leadership increases employee performance by $64.3 \%$ better than before. It shows the crucial role of transformational leaders in employee performance. Partially, organizational culture positively affects employee performance.

Based on the perspective of Robbins [1], a culture that grows stronger, which is triggered by a challenge, can spur the organization towards better development. The challenge of international exposure with the elaboration of the vision and mission forces Bengkulu University to become a global university to develop organizational culture so that it can adapt to the international world. The results of the regression coefficient show that a growing organizational culture can spur a $58.7 \%$ increase in employee performance from before. It shows that organizational culture can also be a factor that plays a vital role in improving employee performance. Partially, innovation behavior positively affects employee performance.

The demand for becoming a global university has made Bengkulu University try to increase the performance output of employees including lecturers, which is reflected in the increasing number of researches. The performance output in the form of the amount of research spurs the teaching force to explore looking for new ideas as the opinion of $\mathrm{Wu}$, Parker \& De Jong [3] who argue that innovation behavior is a form of behavior or problematic work attitudes from individuals who create, introduce or implement new ideas. The results of the regression coefficient also show that innovation behavior can trigger performance by $79.5 \%$, an increase from before. Among other independent variables, the innovation behavior variable is the factor that most influences performance. It is reasonable given the status of the organization 
as an educational and research institution that requires its members to produce research outputs that are closely related to innovation and the search for new ideas.

This study also provides suggestions for organizations and future research on the need for leaders to always build good relationships with subordinates. It is also necessary to study succession planning, namely the process of leadership regeneration, considering that many leaders at Bengkulu University are about to end their tenure. The challenge for current leaders is to transmit their positive habits and to cadre new leaders who also have the characteristics of transformational leaders.

The organizational culture that is growing back must always be maintained. The demand for international exposure demands a flexible organizational culture that is continually changing and adapting to the dynamics of changes that occur mostly in the international world. Innovation behavior needs to be facilitated by all stakeholders in Bengkulu University. Innovation behavior continues to be developed through various methods such as looking for new technological alternatives, formulating new ways to achieve goals, applying new work methods or finding alternative resources to formulate new ideas [17].

\section{References}

[1] Robbins, S. P. Organizational Behaviour: Concepts, Controversies and Applications Australia and New Zealand. Prentice-Hall, 2006.

[2] Schein, E. H. Organizational culture and leadership third edition. John Wiley \& Sons, 2004.

[3] Wu, C. H., Parker, S. K., \& De Jong, J. P. Need for. cognition as an antecedent of individual innovation behavior. Journal of Management, 40(6), 1511-1534, 2014.

[4] Yuan, F., \& Woodman, R. W. Innovative behavior in the workplace: The role of performance and image outcome expectations. Academy of management journal, 53(2), 323- 342, 2010.

[5] Luthans, Fred. Perilaku Organisasi. Edisi Sepuluh, PT. Andi: Yogyakarta, 2006.

[6] Robbins, S. P., \& Judge, T. A. Perilaku organisasi (Organizational behavior). Jakarta: Salemba Empat, 2008.

[7] Cavazotte, F., Moreno, V., Hickmann, M. Effects of leader intelligence, personality, and emotional intelligence on transformational leadership and managerial performance, The Leadership Quarterly, Vol 23, pp. 443 - 455, 2012.

[8] Bass, B.M. Leadership and Performance Beyond Expectation. New York: Free Press, 2003 .

[9] Bass, B.M. Does the Transactional - Transformational Leadership Paradigm Transcend Organizational dan National Boundaries? American Psychologist, 52, 130-139, 1997

[10] Mas'ud, Fuad, Survei Diagnosis Organisasional, Konsep dan Aplikasi. Badan Penerbit Universitas Diponegoro, 2004.

[11] Deshpandé, R., \& Farley, J. U.. Executive insights: corporate culture and market orientation: comparing Indian and Japanese firms. Journal of International Marketing, 7(4), 111-127, 1999.

[12] Stoner, James A.F; Freeman, R. Edward; Gilbert JR, Daniel. R, Manajemen, Jilid I, PT Bhuana Ilmu Populer, 1996. 
[13] Wilderom, C. P., \& Van Den Berg, P. T. (2000). Firm culture and leadership as firm performance predictors: a resource-based perspective. Centre for Economic Research, 2000-03, 2000.

[14] Damanpour, Fariborz. Organizational innovation: A meta - analysis of effects of determinants and moderators. Academy of Management Journal 34(3): 555-590, 1991.

[15] Van de Ven, A. H. Central problems in the management of innovation. Management science, 32(5), 590-607, 1986.

[16] Janssen, O. Job demands, perceptions of effort-reward fairness, and innovative work behavior. Journal of Occupational and organizational psychology, 73(3), 287-302, 2000.

[17] Kanter, R. M. Three tiers for innovation research. Communication Research, 15(5), 509-523, 1988.

[18] De Jong, J., \& Den Hartog, D.. Measuring innovative work behavior. Creativity and innovation management, 19(1), 23-36, 2010.

[19] Howell, J. M., Shea, C. M., \& Higgins, C. A. Champions of product innovations: defining, developing, and validating a measure of champion behavior. Journal of business venturing, 20(5), 641-661, 2005.

[20] Rivai, V., dan Mulyadi, D. Kepemimpinan dan Perilaku Organisasi, Jakarta: Rajawali Pers. 2002

[21] Campbell, J. P., McCloy, R. A., Oppler, S. H., \& Sager, C. E. A theory of performance. Personnel selection in organizations, 3570, 1993.

[22] Ilgen, D. R., \& Schneider, J. Performance measurement: A multi-discipline view. International review of industrial and organizational psychology, 6, 71-108, 1991.

[23] Motowidlo, S. J., Borman, W. C., \& Schmit, M. J. A theory of individual differences in task and contextual performance. Human performance, 10(2), 71-83, 1997.

[24] Shore, L. M., Newton, L. A., \& Thornton III, G. C. Job and organizational attitudes in relation to employee behavioral intentions. Journal of Organizational Behavior, 11(1), 57-67, 1990.

[25] Surya, R. dan S.T. Hananto, Pengaruh Emotional Quotient Auditor Terhadap Kinerja Auditor di Kantor Akuntan Publik, Perspektif. Vol.IX. No.1:33 40, 2004.

[26] Sugiyono. Metode Penelitian Kuantitatif, Kualitatif dan R\&D.Bandung:Alfabeta, 2011.

[27] Malhotra, Naresh K. Marketing Research. New Jersey: Pearson Prentice Hall, 2004.

[28] Ghozali, Imam. Aplikasi Analisis Multivariate dengan Program SPSS.Semarang:UNDIP Press, 2006.

[29] Chen, Li Yueh, "Examining The Effect Of Organization Culture And Leadership Behaviors On Organizational Commitment, Job Satisfaction, Adan Job Performance At Small And Middle-Sized Firma Of Taiwan," Journal of American Academy of Business, Sep 2004, 5, 1/2, 432-438, 2004.

[30] Naranjo-Valencia, J. C., Jiménez-Jiménez, D., \& Sanz-Valle, R. Studying the links between organizational culture, innovation, and performance in Spanish companies. Revista Latinoamericana de Psicología, 48(1), 30-41, 2016.

[31] Priyatno, Dwi. Belajar Cepat Olah Data Statistik dengan SPSS. Yogyakarta: Andi, 2012

[32] Piccolo, R. F., \& Colquitt, J. A. Transformational leadership and job behaviors: The mediating role of core job characteristics. Academy of Management Journal, 49(2), 327-340, 2006 
[33] Walumbwa, F. O., Cropanzano, R., \& Hartnell, C. A. Organizational justice, voluntary learning behavior, and job performance: A test of the mediating effects of identification and leader-member exchange. Journal of Organizational Behavior, 30(8), 1103-1126), 2009.

[34] Amabile, T. M. Creativity in context: Update to the social psychology of creativity. Hachette UK, 1996.

[35] Trottier, T., Van Wart, M., \& Wang, X Examining the nature and significance of leadership in government organizations. Public administration review, 68(2), 319-333, 2008. 